\title{
Obituaries
}

Obituaries should be submitted by email to Kate Maynard at k.maynard@nature.com.

All submitted obituaries should be 400 words maximum in length (apart from obituaries for past presidents of the BDA where the length should be 700-800 words) Content of the obituary is down to the individual author, and the approval of the family should be given for the obituary prior

to submission to the $B D J$.

JOHN BLAIR HARDIE

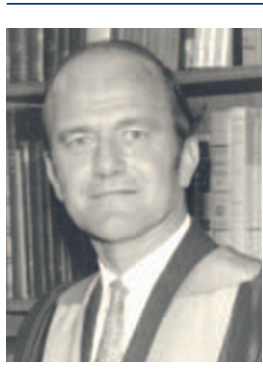

John Blair Hardie died at home in Dundee on Sunday 19 October 2008.

After training at Guy's Hospital, London, he joined the Royal Army Dental Corps, attached to the 4th Cameron Highlanders, and was posted to the Dutch West Indies in 1939.

Later, in Italy, he became part of a team undertaking maxillofacial restoration, and when he came back to Britain he joined Sir Archibald McIndoe's team at East Grinstead. For his services in the specialised field of reconstructive surgery he was awarded the MBE, and subsequently became a Fellow in Dental Surgery, of the Royal College of Surgeons. He bought his dental practice in Montrose in 1949.

He was President of the North of Scotland branch of the BDA between 1960 and 1962 and an active member of the GDC. He sold the Montrose practice in 1973, buying a house in Dundee, and a flat in Edinburgh, where he was a consultant for the Edinburgh Dental Day Hospital at the Western General. During this period he developed a particular interest in working with patients with fear of dentistry, and used both hypnosis and counselling approaches in this work.

At the same time he started training for the priesthood, and was ordained priest in 1976 in Dundee Cathedral. He had a parish at St Martin's, Dundee, for five years. For the following five years he was at Dundee Cathedral. He then became Assistant Priest at the Church of the Holy Rood, Carnoustie, and at St Salvador's Dundee, from which he eventually 'retired' when he was 80 , but still carried on taking a Tuesday service there, until it became physically too difficult.

After the death of his first wife, Margaret, he married Rachel in 1994, and enjoyed her love and care for over 14 years. Now his family includes three children, five grandchildren and three great grandchildren. In the last six years he contended with cancer, a major heart attack and renal failure. These he bore with fortitude and humour; he never lost the merry twinkle in his eye.

His Requiem Mass was on 24 October, at St. Salvador's Church, Dundee. It was attended by clergy and dental colleagues, family, and friends from all over the country, and the day was a fitting end, and celebration, of his 92 years.

R. Hardie

\section{DONALD JAMES TIMMS}

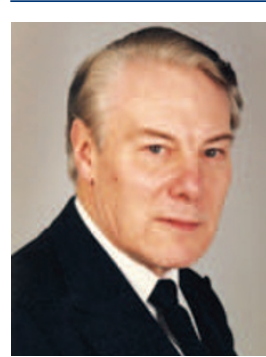

Donald died on 18 November 2008 aged 85 . He was born on 12 June 1923 in Gloucester. When he was 2-years-old his family moved to Monmouth where his father was a well-respected dentist. He was educated at Monmouth School until the age of 18 and then went to Cardiff University to read Civil Engineering. After only one year he enlisted in the RAF and from 1942-1946 he was a pilot flying Lancaster Bombers. He always maintained contact with his crew attending regular reunions.

From 1947-1952 Donald was an undergraduate at Guy's where he was in the rugby team. He moved to UCH for his postgraduate studies first as a House Surgeon then as a Registrar (1953-1955) and Senior Registrar (1955-1961). He performed original research in electromyography with Barry Wyke at a time when it was first introduced into England. Under the tutelage of Willi Grossman he developed a lifelong interest in Rapid Maxillary Expansion (RME).

He was appointed to a consultant post at the Royal Preston Hospital in 1961 and covered an immense area involving eight health districts. He served on numerous local and regional committees and played a pivotal role in developing orthodontic services in North Lancashire and South Cumbria. With vision, foresight and skilful negotiation he established the present pattern of consultant cover with four consultants serving his original patch by the time he retired in 1989.

Donald Timms gained an international reputation for his research on RME and became one of the world's leading exponents of this technique having completed well over 1,000 cases. He always said that the first 500 were the most difficult! He gave lectures and courses all over the world. At his retirement dinner the menu card showed him travelling the world on RME.

As well as numerous publications on RME, Donald was best known for his excellent book on the subject. This is essential reading on the subject; it is difficult to write a paper on RME without referring to Timms.

Donald always emphasised the medical aspects of RME in relation to improvements in nasal airway and worked closely with his ENT colleagues. He foresaw the importance of the nasopharyngeal airway in craniofacial development and obstructive sleep apnoea. The profession is indebted to his pioneering work in this field.

M. J. Trenouth 